IZA DP No. 8929

Income Convergence and the Flow out of Poverty in India, 1994-2005

Paola A. Barrientos Q.

Niels-Hugo Blunch

Nabanita Datta Gupta

March 2015 


\title{
Income Convergence and the Flow out of Poverty in India, 1994-2005
}

\author{
Paola A. Barrientos Q. \\ Aarhus University \\ Niels-Hugo Blunch \\ Washington and Lee University \\ and IZA
}

Nabanita Datta Gupta

Aarhus University

and IZA

Discussion Paper No. 8929

March 2015

IZA
P.O. Box 7240
53072 Bonn
Germany

Phone: +49-228-3894-0

Fax: +49-228-3894-180

E-mail: iza@iza.org

Any opinions expressed here are those of the author(s) and not those of IZA. Research published in this series may include views on policy, but the institute itself takes no institutional policy positions. The IZA research network is committed to the IZA Guiding Principles of Research Integrity.

The Institute for the Study of Labor (IZA) in Bonn is a local and virtual international research center and a place of communication between science, politics and business. IZA is an independent nonprofit organization supported by Deutsche Post Foundation. The center is associated with the University of Bonn and offers a stimulating research environment through its international network, workshops and conferences, data service, project support, research visits and doctoral program. IZA engages in (i) original and internationally competitive research in all fields of labor economics, (ii) development of policy concepts, and (iii) dissemination of research results and concepts to the interested public.

IZA Discussion Papers often represent preliminary work and are circulated to encourage discussion. Citation of such a paper should account for its provisional character. A revised version may be available directly from the author. 


\begin{abstract}
Income Convergence and the Flow out of Poverty in India*

This paper explores the dynamics of income and poverty of rural Indian households, 19942005. The estimation strategy consists of convergence analysis to test whether poor households are catching-up in terms of income, followed by transition analysis to test whether poor households are more likely to exit poverty than to remain poor. The identification strategy explicitly addresses issues pertaining to the potential endogeneity and measurement error of initial income and poverty. We find evidence of income convergence and a higher probability of exiting poverty than of remaining poor. The key variables driving these results are education, occupation and asset ownership.
\end{abstract}

JEL Classification: $\quad 012,047,053$

Keywords: income convergence, poverty transition, endogeneity, measurement error, IHDS \& HDPI data

Corresponding author:

Nabanita Datta Gupta

Department of Economics and Business

Aarhus University

Fuglesangs Allé 4

8210 Aarhus V

Denmark

E-mail: ndg@econ.au.dk

\footnotetext{
* These results are based on the India Human Development Survey, 2004-05, and the Human Development Profile of India 1993-94. The IHDS survey was jointly organised by researchers at the University of Maryland and the National Council of Applied Economic Research. The data collection was funded by grants R01HD041455 and R01HD046166 from the National Institutes of Health to the University of Maryland. Part of the IHDS sample represents a resurvey of households initially interviewed in the course of the Human Development Profile of India 1993-94 conducted by NCAER. The authors would like to thank participants of the $9^{\text {th }}$ Annual Conference on Economic Growth and Development in New Delhi, the Center for Studies in Social Sciences-Calcutta Seminar Series, the $55^{\text {th }}$ Annual Conference of the Indian Society of Labour Economics, the $2^{\text {nd }}$ annual IHDS User's Conference, and workshops at Washington and Lee University and Aarhus University for their helpful comments and suggestions which have improved the paper.
} 


\section{Introduction}

This paper explores the dynamics of income convergence and the flow out of poverty of Indian rural households, 1994-2005. The concept of convergence has been typically used to evaluate inequalities among incomes of different countries or regions with aggregated data. Recent research, however, has used household data as well, which allows for a broader perspective of convergence. Ravallion (2012) uses household data to study not only income but also poverty convergence among 100 developing countries. He claims that income convergence should lead to poverty convergence: poorer families grow faster and catch-up in terms of their incomes, which makes them less poor and thus they also catch-up with respect to their poverty levels with higher proportionate rates of poverty reduction. Nevertheless he finds that there is income but not poverty convergence under the argument that poverty itself restricts poverty convergence, also known as "poverty traps".

In this context, India is a country characterised by its high growth rates but also by its widespread inequalities, hinting at the possibility of the presence of poverty traps. India's high growth rates are attributed to its liberalisation reforms undertaken since the 1990s, which are associated with an expansion of capital and skill-intensive exports (e.g. software and business services, pharmaceuticals, vehicles, auto parts, and steel, among others). This pattern of development contrasts sharply with the Chinese case which has been more manufacturingcentred (Bardhan, 2007).

The kind of development path which India has followed seems to have been mainly benefited the urban sectors up to now, and in fact, earlier research has shown that the liberalisation 
process exacerbated regional disparities between urban and rural areas (Deaton and Dreze, 2002). Thus, despite the strong economic growth that India has experienced, the results for welfare have not been successful (Deaton and Dreze, 2002). Recent studies show that the poverty decline in India has been slower than in other LDCs (Lenagala and Ram, 2010) ${ }^{1}$. The main explanation seems to be the nature of the development path, which has benefited mostly high-skilled people that live in urban areas rather than the majority of people who live in the rural areas and work in the agricultural sector (Cain et al., 2010). In China and other Asian countries, on the other hand, the manufacturing-intensive growth pattern adopted there benefited a much larger share of the population (Kotwal et al., 2011).

Over time, however, the process of liberalisation may have generated some positive externalities for rural areas. Kotwal et al. (2011) mentions that a major contribution of the liberalisation process to agricultural growth is likely to be a diversification effect as rising incomes lead to greater urban demand for higher-valued edible oils, milk, fruits and vegetables than staple food cereals in the longer run. Another positive spillover acts through remittances to rural households from family members migrating to urban areas (Parida and Madheswaran, 2010).

Traditionally, inequality has been linked to the rigid stratification of Indian society according to caste and socioreligious background ${ }^{2}$. In fact, both Singh (2010) and Desai and Dubey (2011) find that the caste system generates inequalities. Singh (2010) decomposes net farm income inequality and finds that caste explains a substantial part of it. Similarly, Desai and Dubey (2011) find persistent caste disparities in education, income, and social networks. 
Other research shows, however, that intergenerational social mobility can occur despite the caste system. Hnatkovska et al. (2013) use the household level National Sample Survey (NSSO) data from 1983-2005 to examine the economic progress of sons compared to their fathers in terms of income, education, and occupation. They find that when comparing the most disadvantaged groups, namely the Dalits (SCs) and Adivasis (STs) to the most advantaged, there is significant intergenerational mobility in all of these dimensions, including significant occupational upgrading by sons as compared to their fathers. Examining a longer time-period Azam and Bhatt (2012) find that there has been significant improvement in educational mobility across generations in India (since the 1940s) at the aggregate level, across social groups, and across states.

As a result, several questions arise, what has happened in welfare terms in rural areas in the decade following liberalisation? Are rural households worse off in terms of income inequality and poverty reduction or did they actually benefit from the liberalisation process? Are there signs of poverty traps? What is the role of socioreligious grouping, if any?

Two earlier papers have attempted to answer some of these questions. A recent article by Jha et al. (2013) models the vulnerability to poverty by using panel data for rural India for the period 1999-2006 (3,628 observations in both years). They find evidence for the existence of a poverty trap in the sense that ex ante vulnerability of being poor in 1999 translates into ex post poverty in 2006. Instead, we use a much larger data set and compare income to poverty outcomes. On the other hand, Krishna and Shariff (2011) examine the same data studied here and compare those households that exit poverty to the ones that enter poverty, treating them as 
two different independent samples. We do not split the sample, rather we use the whole sample for our calculations.

We intend to answer all the questions raised above, by using a unique panel data set of Indian rural households (more than 13,000 households) observed during 1993-1994 and 20042005. This allows us to trace economic welfare over time in the rural sector, paying particular heed to how vulnerable low caste and religious minority households have fared over time compared to the high castes. Thus, we are able to provide rich micro-data based evidence on the longer run effects of liberalisation at the level of the household taking the dynamics into account in a conditional analysis.

We assess inequalities and poverty traps, by studying poverty transitions and income convergence, which take into account the potential effect of initial conditions on catching-up in income/exiting poverty. Simultaneously we establish the main income growth determinants at the household level as well as the determinants of poverty outcomes. We focus on the role of caste (separating Dalits, Adivasis, OBCs and High-castes) but also on the role of religion. According to the 2006 Sachar Committee Report, Muslims are also a disadvantaged group in India, and there is no reservation policy ${ }^{3}$ for this group currently. Moreover, we explore whether we capture different welfare concepts when using a continuous variable for income as compared to the binary variable for poverty.

The paper is organised as follows. We first describe the dataset and the most important variables in our models. Then we present our empirical strategy. After that we discuss our findings and finally, we present the conclusions, discuss policy implications, and provide suggestions for future research. 


\section{Data}

\subsection{Data description}

Our data set is based on 13,081 households that were interviewed in two different waves. During the year 1993 to 1994, the survey known as "Human Development Profile of India" (HDPI), carried out by the National Council of Applied Economic Research (NCAER), consisted of 33,230 households in rural areas only. Later, during 2004 and 2005, the survey denoted "India Human Development Survey (IHDS)” collected information for a total of 41,554 households situated both in rural and urban areas; this survey was conducted by NCAER and the University of Maryland (Desai et al., 2009). From the first survey, a random sample was selected to be reinterviewed in the second survey. However, the original 1993-1994 survey was not randomly selected. With that concern, a new random sample was chosen from rural areas to be compared to the re-interviewed sample in order to determine whether the re-interviewed sample was overrepresented among certain segments of the society. The comparisons suggest that on most variables of interest such as caste, religion, education, and economic status, the re-interviewed sample does not differ substantially from the fresh sample (see Table 1).

The re-interviewed sample consists of a total of 13,081 households, from which $82 \%$, or 10,791 households, were contactable for re-interview and the rest, 2,290 households, had separated from the original household but were still living in the same village, so they were contacted for an interview, as well.

(Table 1 here) 
A main characteristic of the IHDS survey is that the household income variable is built from 50 different separate components. Although the disaggregation in detail is available only for 2005, the total income of households is comparable across waves, Shariff (2009). The 50 components can be aggregated into fewer components, as follows. Farm income: IHDS asked about crop production and prices, usage of crop residues, animal ownership and homeproduced animal and crop products, expenditures on a variety of farm inputs, and net payments on agricultural rents; wage and salary income: consist of all wages in the household, meals, housing benefits, and bonuses; remittances; non-farm business income, government benefits: include scholarships, pensions, maternity scheme, NGO or other assistance, and other government transfers; and others: include income from rental property, interest, pensions and other income.

In 2005, some households from our sample reported negative incomes, more specifically, farming income. These households reported crop failures and high farm expenses. The survey designers confirm that the negative numbers are correct but they advise working with positive incomes higher than 1000 Rs (Desai and Vanneman, 2008). Therefore, our sample is reduced to 12,352 households. In terms of the household composition in our sample, 59\% are adults, 7\% older people and $34 \%$ are children. As much as $95 \%$ of household heads are male and $60 \%$ of them are below 30 years of age, 52\% are illiterate and 48\% are engaged in agriculture (additional descriptive statistics can be found in Table A.1).

\subsection{Variables}


We are interested in measuring the financial situation of households in rural areas. We have at our disposal the variable income, which is directly related to financial position, at least in theory. However, in practice, income may be incorrectly measured due to a variety of reasons (more on this in Section 3.1). Therefore we use food consumption expenditures as a proxy for income, as well.

Figure (1) shows the household per capita income distribution for both waves ${ }^{4}$. The distributions look roughly similar for both years. The 2005 income distribution is somewhat smoother at the top and also somewhat wider. This is confirmed by the higher standard deviation in 2005 as compared to 1994 (see Table A.1 in the Appendix). This is a sign of increasing inequality, since it implies that the distribution became more unequal over time. However, we have to remember that these are the unconditional distributions without controlling for other factors.

As for income, also the standard deviation of consumption expenditure has increased from 1994 to 2005. Figure (1) shows the distribution of food consumption as compared to income. As expected, the distribution of food consumption is narrower, since people tend to fulfil their food needs first ${ }^{5}$.

(Figure 1 here)

Turning next to the explanatory variables, our household level variables consist mainly of characteristics of the head of the household ${ }^{6}$. We include education, age, occupation, gender, and reported caste of the head and asset ownership. Finally, regional (geographic) 
characteristics are captured via dummies for each of the states. These variables capture, among other things, political and job reservations as well as locally economic conditions pertaining to the state in question.

To calculate poverty estimates ${ }^{7}$, we use the national poverty lines provided by the Planning Commission of India which in contrast to the World Bank's 1.25 US dollar a day for any country give different lines for each state and for rural and urban areas. As Krishna and Shariff (2011), we do not deflate income from 1994. Instead, we compare current income with the official poverty line year by year ${ }^{8}$. As mentioned in Krishna and Shariff (2011), the results are not directly comparable with other estimates that are based on consumption ${ }^{9}$.

According to our population estimates of poverty incorporating IHDS design weights, poverty has increased from 37\% in 1994 to $41 \%$ in 2005 (see Table 2). This does not mean that all households were worse off in 2005 compared to 1994. For example, about 22\% of the households managed to leave poverty, and $41 \%$ stayed non poor. The results are driven by those that entered poverty, $18 \%$, and by those $19 \%$ that remained poor throughout the entire period. Note that the finding of a poverty increase over this period is not unusual (Deaton and Kozel, 2005).

(Table 2 here)

We can also examine poverty flows in terms of socioreligious group. The Brahmin and Forward castes (jointly denoted as High caste) had greater positive outcomes than negative ones: 56\% remained non poor and 19\% left poverty. The minorities had a similar pattern: 
$63 \%$ stayed non poor and $14 \%$ left poverty. In contrast, $32 \%$ of the Adivasis entered poverty, and 22\% stayed poor. The numbers are similar for the Dalits and Muslims (Table 3).

(Table 3 here)

In regional terms we also have contrasting outcomes. The Northern, Western and Southern regions perform better than the rest of the regions. For example, $56 \%$ of the households in the Northern region remain non poor in both years, while in the Upper Central Region, only $32 \%$ are non-poor in both years.

\section{Empirical strategy}

\subsection{Income convergence}

We study the dynamics of income by examining income growth and its determinants by considering the following equation:

$$
g_{y_{i}}=\boldsymbol{x}_{\boldsymbol{i}}^{\prime} \boldsymbol{\alpha}_{\boldsymbol{y}}+\beta_{y} \cdot y_{0_{i}}+\varepsilon_{y_{i}}
$$

(1)

$$
\varepsilon_{y} \sim N\left(0, \sigma_{y}\right)
$$


where gyi is the annual growth rate of income of household $\mathrm{i}$ during the period 0 to $\tau$; $\mathrm{y}_{0} \mathbf{i}$ is the income at the beginning of the period measured in logarithms; the vector $\mathbf{x i}$ includes a constant and all the controls (education, occupation, caste, gender and age of the head plus age composition of the household, assets, state dummies and the split dummy to control for the households that split from the first survey). Finally $\varepsilon_{y}$ is the error term and is assumed to be normally distributed.

The coefficient $\beta_{y}$ measures the relationship between initial income and growth, after controlling for household and geographic characteristics. When $\beta_{\mathrm{y}}$ is negative, the poorer the household the more it will grow in comparison to the richer households, holding everything else constant.

Some of the explanatory variables in Equation (1) are predetermined, such as caste, gender and age of the head of the household. However, other variables such as occupation and education of the head may be simultaneously determined or create some reverse causation with respect to income growth. Therefore, in order to avoid simultaneous relations, we include all our explanatory variables observed at the beginning of the period ${ }^{10}$.

On the other hand, we know that our income variable has potential measurement error problems. Measurement error in self-reported surveys is well known and documented. It may be that the persons interviewed are not able to report the precise value of income. One could argue that the misreport is caused by age, education, or some other characteristic of the individual being interviewed, which will necessarily introduce a bias (specifically, attenuation bias, see Wooldridge, 2002). Additionally, measurement error is also a potential concern for rural households, for which it is potentially difficult to derive an accurate report of the value of produce 
from subsistence farming. Many studies argue for using household expenditures instead of household income as the measure of welfare. The reasons for this are several. First, expenditures are measured more accurately than income (Glewwe, 1991) as it is easier to recall expenditures on consumption than income. Second, following the permanent income hypothesis, it may reflect longer term economic status better (Appleton, 2001). If we see a similar convergence pattern employing consumption, we are more convinced that is not just a transitory shock that is driving the finding. This is especially the case if additionally stratifying by caste and religion produces similar results. Therefore, we use a subset of household expenditures as a proxy for income and estimate our growth equation in terms of consumption expenditure as well,

$$
g_{c_{i}}=\boldsymbol{x}_{\boldsymbol{i}}^{\prime} \boldsymbol{\alpha}_{\boldsymbol{c}}+\beta_{c} \cdot c_{0_{i}}+\varepsilon_{c_{i}}
$$

$$
\varepsilon_{\mathrm{c}} \sim \mathrm{N}\left(0, \sigma_{\mathrm{c}}\right)
$$

which is identical to (1), except that instead of household income, y, we are now modelling household consumption, c.

\subsection{Poverty flows}

To confirm our results on income convergence, we estimate a model of poverty transition ${ }^{11}$. Since our poverty measure is a binary variable we choose not to work with a growth model because its interpretation is not as straightforward. Instead we choose to work with probit models, which yield more intuitive results, in terms of poverty probabilities ${ }^{12}$. We start with a 
simple probit model that accounts for initial poverty status as an explanatory variable for final poverty status,

$$
p_{\tau_{i}}=\mathbf{1}\left(\boldsymbol{x}_{\boldsymbol{i}}^{\prime} \boldsymbol{\alpha}_{\boldsymbol{p}}+\beta_{p} \cdot p_{0_{i}}+\varepsilon_{p i}>0\right)
$$

(3)

$$
\varepsilon_{p} \sim N(0,1)
$$

where $\mathrm{P} \tau_{\mathbf{i}}$ is our poverty dummy variable, being 1 when poor (below the poverty line) and 0 when non-poor in the last year of the period, and $\mathrm{p} 0 \mathbf{i}_{\mathbf{i}}$ is the poverty dummy variable in the initial year. As before, the vector $\mathbf{x i}$ includes a constant and all the controls.

We also estimate a recursive biprobit $\operatorname{model}^{13}$, where initial poverty status becomes endogenous and is determined by the same explanatory variables plus land,

$$
\begin{aligned}
& p_{\tau_{i}}=\mathbf{1}\left(\boldsymbol{x}_{\boldsymbol{i}}^{\prime} \boldsymbol{\alpha}_{\tau_{p}}+\beta_{\tau_{p}} \cdot p_{0_{i}}+\epsilon_{\tau_{p i}}>0\right) \\
& p_{0_{i}}=\mathbf{1}\left(\boldsymbol{x}_{\boldsymbol{i}}^{\prime} \boldsymbol{\alpha}_{\boldsymbol{0}_{p}}+\delta_{0_{p}} \cdot \text { land }_{i}+\epsilon_{0_{p i}}>0\right)
\end{aligned}
$$

(4)

$$
\begin{aligned}
& E\left[\epsilon_{\tau_{p i}}\right]=E\left[\epsilon_{0_{p i}}\right]=0 \\
& \operatorname{Var}\left[\epsilon_{\tau_{p i}}\right]=\operatorname{Var}\left[\epsilon_{0_{p i}}\right]=1 \\
& \operatorname{Cov}\left[\epsilon_{\tau_{p i}}, \epsilon_{0_{p i}}\right]=\rho
\end{aligned}
$$

where $\rho$ is the correlation coefficient of the unobservables of each of the equations. The objective is to account for the correlation between the error terms of the two individual 
equations and, thus, to infer the importance and direction of the unobservables as drivers of the two individual equations/poverty statuses in the two periods. In comparison to the normal probit model, the bivariate probit analyses can yield useful estimates such as conditional probabilities (e.g., the probability of being non poor in 2005 given that one was poor in 1994). For identification purposes, we restrict the variable land to enter only through the initial poverty variable due to its pre-determinedness. This approach in fact resembles an IV procedure where land is the instrument for initial poverty. We discuss the assumption of having land ownership as instrument in Section 4.1.1.

We compare poverty outcomes given equal initial conditions. There is a flow out of poverty when the probability of ending non-poor is higher than ending poor in 2005 given that one was poor in $1994^{14}$ :

$$
\operatorname{Pr}\left(p_{\tau}=0 \mid p_{0}=1\right)>\operatorname{Pr}\left(p_{\tau}=1 \mid p_{0}=1\right)
$$

\section{Results}

\subsection{Income convergence}

Table 4 reports the estimated results from Equations (1) and (2) in columns 1 and 2 respectively. We first analyse the determinants of income/consumption growth and later we analyse the convergence parameters.

For both income and consumption growth, education is very important. The education coefficients are higher for income than consumption. All socioreligious groups, compared to high 
caste, appear to have both statistically and substantively significant negative effects on income and consumption growth, except for minorities. Again, the importance of socioreligious grouping is more negative for income than consumption, and the worst off are Muslims. In a similar fashion assets seem to have a higher impact on income than consumption. None of the occupations, in comparison to an occupation in agriculture, are important for food consumption while all of them are important for income, especially when the head of the household owns his or her own business. In contrast, the household's annual expenditures on education seem to be relevant only for income growth.

(Table 4 here)

Regarding the beta convergence coefficients, they are very similar, $\beta_{\mathrm{y}}=7.6 \%$ and $\beta_{\mathrm{C}}=$ 7.9\%, and imply a half-life of 9 years, see Table A.3. The fact that both speeds of convergence are so similar can hint at two different things. First, that measurement error in income is not as bad as expected so that food consumption is a good proxy for income. Or, second, that there is measurement error both in initial income and in consumption compared to the final outcomes, which when captured by the $\beta$ parameter makes the speeds of convergence similar. Furthermore, measurement error in the initial variable can lead to high speeds of convergence. For example, when initial income is below its true value, the growth rate will appear higher than it should be, showing convergence. Therefore, we now examine the second possibility. 


\subsubsection{Sensitivity analysis}

Initial income may be endogenously determined because the measurement error that it may contain may be related to the error term in the growth model since initial income enters also in the RHS. We re-write Equation 1 in levels ${ }^{15}$ :

$$
y_{\tau_{y_{i}}}=\boldsymbol{x}_{\boldsymbol{i}}^{\prime} \boldsymbol{\alpha}_{\tau y}+\beta_{\tau y} \cdot y_{0_{i}}+\varepsilon_{\tau y_{i}}
$$

(5)

$$
\varepsilon_{\tau y} \sim N\left(0, \sigma_{y_{\tau}}\right)
$$

Equation (5) can be estimated instead of Equation (1) without loss of generality, the only difference is that the parameters are scaled in a different way. We recover the original growth parameters by dividing by $\tau$, except the $\mathrm{y}_{0}$ parameter, which needs to be subtracted by one and then divided by $\tau$.

Then we instrument our potentially endogenous variable, initial income, with land ownership. Land ownership is often inherited and therefore exogenously determined (Glewwe, 1991). The land market in India is very tight or even almost non-existent due to inheritance and

ownership rules ${ }^{16}$. Morris (2002) points out that the land markets are highly distorted and inefficient; land records are inaccurate, outdated, and incomprehensible and transaction costs are high by international standards, all of which have discouraged formal land transactions.

We suggest that it is reasonable to assume that land ownership is exogenous to income growth, that it is predetermined and cannot, therefore, be simultaneously determined with income growth. However, it could be related to growth through unobservable variables such as 
changes in international food prices. An increase in food prices, while keeping land constant, increases household income. In our case, a change in international food prices between our two points in time would be the same for all households. Therefore, we suggest that this is captured by the constant. Another possible omitted variable could be land efficiency which we suggest is captured by our asset variable which includes productive assets. However, of course we realise that ultimately land matters for income. Therefore we also assume that land is related to initial income rather than to growth, which implies that land explains growth only via initial income ${ }^{17}$.

The results are shown in Table 5 and column 3 shows the re-calculated growth parameters. Regarding the determinants of income growth, we can see that after using our instrument, the impact of the most important determinants has decreased a bit. However the same variables are still statistically significant. Surprisingly the $\beta_{y}$ remains close to the previous results: $\beta_{y}=$ $6.9 \%{ }^{18}$. Therefore, we are confident that our previous results are robust, especially given that no other instrument is available. It is worth noting that the exogeneity tests indicate that initial income is indeed exogenous (see Table A.3). ${ }^{19}$

(Table 5 here)

\subsection{Poverty flows}

Next, we examine the results of our probit and biprobit models (Equations (3) and (4), respectively). In the first case, initial poverty is restricted to be exogenous and in the second case, 
initial poverty is allowed to be endogenous. In both cases, the original estimations are presented in the Appendix (Table A.4). It is not intuitive to interpret the coefficients from Table A.4 directly. Therefore, we calculate the average marginal effects. For the probit case the average marginal effect of each explanatory variable is evaluated at the outcome of $\operatorname{Pr}(\operatorname{poor} 2005=1)$ while for the biprobit case, the average marginal effect is evaluated at the conditional probability of $\operatorname{Pr}($ poor2005=1|poor1994=1), which we call "conditional probability of poverty". We choose to work with conditional probabilities instead of joint probabilities because they resemble regression coefficients by showing the effect of different explanatory variables of the conditional mean, i.e. slopes of conditional expectations (Greene, 2008). The results are shown in Table 6.

(Table 6 here)

The estimated parameters are very similar for both probit and biprobit models. Actually the Wald test of $\rho$, that indicates whether the correlation of unobservables is zero, suggests that we should accept the null (last line in Table A.4). However, we still continue with the biprobit analysis in order to obtain the conditional probabilities. In the end, the results are not wrong, and imply just that we are using a more general model than needed as it takes into account the potential correlation of unobservables and the potential influence of land ownership.

Regarding the determinants of the conditional probability of remaining in poverty, we find that primary and middle education levels reduce such a probability. Regarding occupation, professional and own business jobs lower such a probability too. Being from OBC, SC, ST or 
being Muslim increases the conditional probability of poverty, with the Muslims faring the worst. Further, Table 7 shows the joint and conditional predicted probabilities for the total sample, for each of the socioreligious groups and regions.

(Table 7 here)

We suggest that it is potentially interesting to examine the conditional probability of exiting poverty, $\operatorname{Pr}($ poor2005=0 $\mid$ poor1994=1). The joint probability instead, $\operatorname{Pr}($ poor2005=0, poor1994=1) is just indicative but not as interesting in our case. To make our point, we can see that the joint probability of exiting poverty is $20 \%$ and by socioreligious group, it looks like the most disadvantaged groups (Dalit, Adivasi and Muslim) have a higher probability of exiting poverty ( $24 \%, 22 \%$ and $22 \%$, respectively). However, if we consider instead the conditional probability of exiting poverty, we see that for the total sample, it is $63 \%$. By examining the estimated probabilities by socioreligious group, we see that the High caste and minorities have the highest conditional probabilities of exiting poverty ( $75 \%$ and $86 \%$, respectively). Thus the conditional probability is taking into account the previous state of poverty, which, we argue, is the correct thing to do when allowing for the existence of poverty traps.

Considering regional variation, the conditional probability of exiting poverty is highest for the Northern (78\%) and for the Southern region (73\%). By contrast it is lowest for the Upper Central (54\%) region. Similarly the conditional probability of staying non-poor, $\operatorname{Pr}($ poor2005=0 poor1994=0), is the highest for the Northern (75\%) and Southern (70\%). 
Regarding our poverty results, when conditioned on initial poverty, the probability of ending non-poor is higher than ending poor:

$$
\operatorname{Pr}\left(p_{\tau}=0 \mid p_{0}=1\right)=63 \%>\operatorname{Pr}\left(p_{\tau}=1 \mid p_{0}=1\right)=37 \%
$$

We find the same relation within all socioreligious groups, namely that the probability of exiting is higher than the probability of remaining in poverty. However for the Adivasis and Muslims the difference is not as high. In general, we find no evidence of poverty traps and instead we find that poverty is declining and, thus, the poor will not stay poor.

\section{Discussion}

\subsection{Comparison with previous research}

The main difference between our analysis and that in Krishna and Shariff (2011) is that even though they separate their sample by the household's poverty situation in 1994, it is not the same as conditioning on the initial poverty status (as we do). They essentially re-sample their analysis. First, they choose those households that were poor in 1994 and non-poor in 2005 and then they choose households that were not poor in 1994 and poor in 2005. Instead we work with the whole sample and with conditional outcomes. Regarding the explanatory variables, they include community characteristics, and we do not, out of a concern for endogeneity due to 
location choice. Plus, they include variables from 2005, which we try to avoid due to potential simultaneity.

Although the methodology in Jha et al. (2013) is very different, we try to compare our findings with some of their results. To begin with, they measure the vulnerability of being poor as the probability of entering poverty and staying poor. Later, they include their vulnerability measure in their initial year in a multinomial logit to obtain outcomes of different combinations. From all those results combined we think the result that is most comparable to our conditional probability would be the poor-poor result. They find that education is very important just as we do. However, the other variables are defined differently and hence difficult to compare.

\subsection{Migration}

In the introduction we mentioned that although rural India has not gained from the skill biased pattern of development since the 1990s, studies show that the rural sector has indirectly benefited from rural-urban migration, in particular, from remittances. Data from the NSSO 64th round (2007-2008) show that the average yearly consumption expenditures for rural households receiving remittances was Rs. 41,000 as compared to Rs. 38,000 for rural households not receiving remittances, and that 36.5\% of rural households received such remittances (Parida and Madheswaran, 2010). Remittances, therefore, are an important source of income and consumption-smoothing for certain rural households and this may have had consequences for rural incomes and poverty in recent years.

Unfortunately our sample of households only includes those families who have actually stayed in the rural areas in the period under study. This means that our sample is restricted to 
the households that have not migrated. However, one or more family members may have migrated. We do not have information on whether or not a member has migrated in 1994 but our total household income measure includes remittances in any case.

In the literature migrants are generally found to be positively self-selected in terms of both observables and unobservables. However, their economic performance after migration could vary depending on job availability in urban areas and many could actually be worse-off after migrating if they do not possess the skills demanded in urban labour markets in India which have experienced skill-biased technological change in recent times. Therefore the potential selection bias could go in either direction.

A drawback of our data is that we cannot separate remittances from the total income in the survey in 1994 but only in 2005; furthermore we do not have detailed information on remittances. Therefore we exploit only the information on household total remittances in 2005 to analyse its effects on convergence.

Only 6\% of our sample received remittances in 2005 (not as many as claimed by Parida and Madheswaran, 2010). We augment the convergence and poverty analysis by now including a dummy for those households that received remittances in $2005^{20}$. The results show no significant differences from the ones discussed previously ${ }^{21}$.

\section{Conclusions}

This paper explores the dynamics of income in rural Indian households over the period from 1994 to 2005, when India underwent several liberalisation reforms, by examining the timeconditional inequality measures of income convergence and flows out of poverty. The 
identification strategy explicitly addresses issues pertaining to the potential measurement error in income and the potential measurement error in initial income and poverty.

Despite the fact that the raw data shows increasing inequality in income and increased poverty rates over this period, we find that there is evidence of income and poverty convergence which indicates that poverty traps are escapable and that poor households are indeed catching up to the rich households.

Among the most important results we find that education, occupation (in particular selfemployment) and asset ownership are crucial for income accumulation and also for poverty reduction. One policy recommendation would be to provide access to productive assets to families and at the same time increase public expenditures on education in rural areas, perhaps emphasizing training in usage of such assets to promote entrepreneurship.

Another robust finding running through income to poverty convergence is that the lower castes (Dalits and Adivasis as well as OBCs) as well as Muslims, show less income growth and slower poverty convergence than the High castes and Minorities. This is the case despite decades of reservation policies for Dalits and Adivasis, suggesting that these groups require further attention in future inequality reducing measures and so do OBCs and Muslims.

Extensions could consider incorporating the effects of migration and searching for alternative instruments (within the confines of the previously mentioned issues regarding these issues). In the future the survey will be conducted again which will allow us to exploit one more wave of data to confirm our currents results on income convergence and poverty transition for households in rural India. 


\section{References}

Appleton, S. (2001). The rich are just like us, only richer: Poverty functions or consumption functions? Journal of African Economies 10(4), 433-469.

Azam, M. \& Bhatt V. (2012, May). Like father, like son? Intergenerational education mobility in India (IZ A Discussion Paper No. 6549), Bonn: IZA.

Banerjee, A. \& Iyer L. (2005). History, institutions, and economic performance: The legacy of colonial land tenure systems in India. American Economic Review 95(4), 1190-1213.

Bardhan, P. (2007). Poverty and inequality in China and India: Elusive link with globalisation. Economic and Political Weekly 42, 3849-3852.

Cain J. S., Hasan, R. Magsombol, R . \& Tandon A . (2010, March). Accounting for inequality in India: Evidence from household expenditures. World Development 38(3), 282-297.

Deaton, A. \& Dreze J. (2002, September). Poverty and inequality in India: A re-examination (Working Papers No. 184). Princeton University: Woodrow Wilson School of Public and International Affairs, Research Program in Development Studies.

Deaton, A. \& Kozel V. (2005). The great Indian poverty debate. Macmillan.

Desai, S. \& Dubey A. (2011). Caste in 21st century India: Competing narratives. Economic and Political Weekly 46(11), 40-49.

Desai, S., Dubey, A., Joshi, B.L., Sen, M., Shariff, A., \& Vanneman R. (2009). India human development survey: design and data quality. IHDS technical paper (1).

Desai, S. \& Vanneman R. (2008). India human development survey (IHDS) (Working paper) Inter-university Consortium for Political and Social Research. 
Glewwe, P. (1991, April). Investigating the determinants of household welfare in Cote d'Ivoire. Journal of Development Economics 35(2), 307-337.

Greene, W.H. (2008). Econometric Analysis. Prentice Hall.

Hnatkovska, V., Lahiri, A., \& Paul S.B. (2013). Breaking the caste barrier intergenerational mobility in india. Journal of Human Resources 48(2), 435-473.

Iversen, V., Kalwij, A. Verschoor, A., \& Dubey A. (2014). Caste dominance and economic performance in rural India. Economic Development and Cultural Change, 62(3), 423-457.

Jha, R., Kang, W., Nagarajan, H.K., \& Pradham K.C. (2013). Vulnerability as expected poverty in rural India. ASARC Working Papers No. 2013-12.

Jolliffe, D. (2002, January). Whose education matters in the determination of household income? evidence from a developing country. Economic Development and Cultural Change 50(2), 287-312.

Kotwal, A., Ramaswami, B., \& Wadhwa W. (2011). Economic liberalization and Indian economic growth: What's the evidence? Journal of Economic Literature 49(4), 1152-1199.

Krishna, A., \& Shariff A. (2011, April). The irrelevance of national strategies? rural poverty dynamics in states and regions of India, 1993-2005. World Development 39(4), 533-549.

Lenagala, C., \& Ram R. (2010). Growth elasticity of poverty: estimates from new data. International Journal of Social Economics 37(12), 923-932.

Morris, D. (2002, January). Land markets in India: Distortions and issues. Economic Development and Cultural Change 50(2), 287-312.

Oldiges, C. (2012, February). Cereal consumption and per capita income in India. Economic and Political Weekly 50(2), 287-312. 
Parida, J.K., \& Madheswaran S. (2011). Determinants of migration and remittance in India: Empirical evidence. The Indian Journal of Labour Economics 54(3), 561-578.

Ravallion, M. (2012). Why don't we see poverty convergence? American Economic Review 102(1), 504-523.

Shariff, A. (April/June 2009). Rural income and employment diversity in India during 1994 and 2005. Journal of Developing Societies 25(2), 165-208.

Singh, A. (2010, July). Does returns to farming depend on caste? new evidence from India (MPRA Paper 26526). University Library of Munich, Germany.

Wooldridge, J.M. (2002). Econometric Analysis Cross Section Panel. MIT press. 
Figure 1: Kernel density plot for food consumption expenditure and income per capita

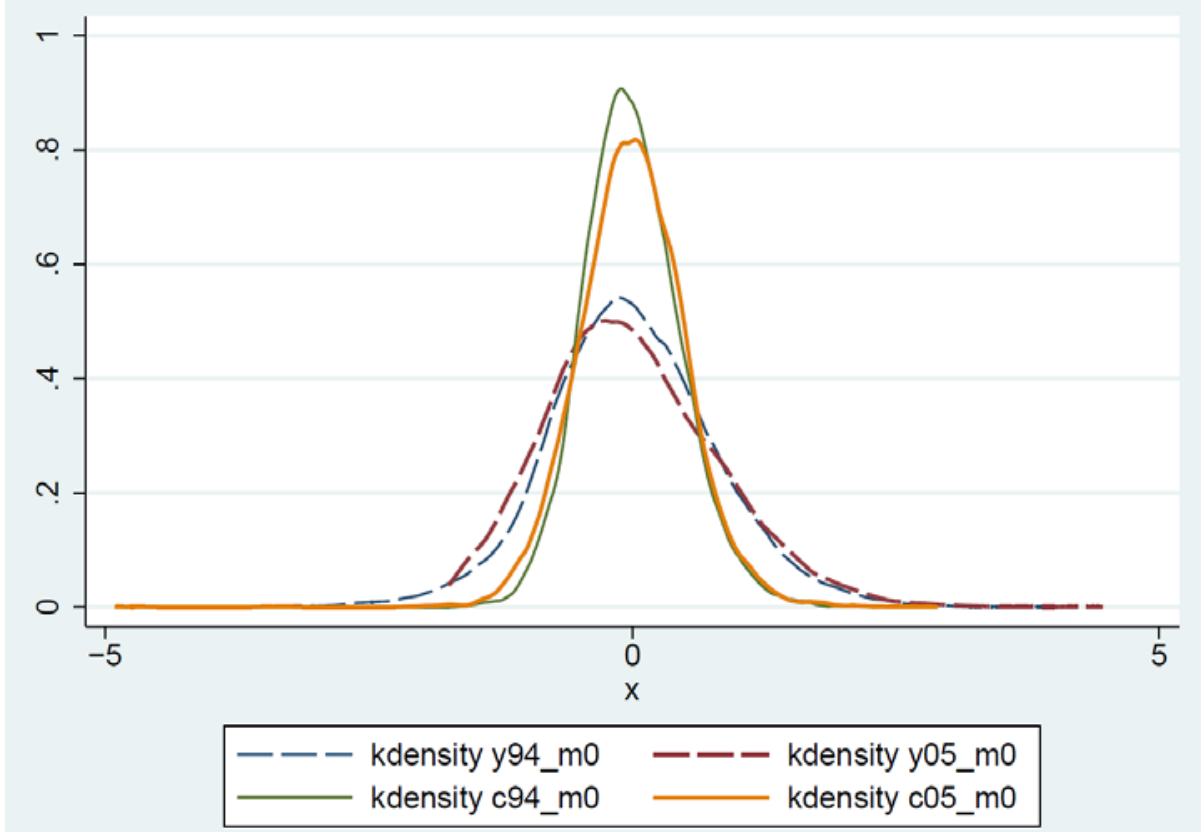

Note: All variables are demeaned. We use the Consumer Price Index for Agricultural and Rural Labourers (CPI-AL) to transform the 1994 data to 2005 prices. $y$ is income and c is food consumption per capita. 
Table 1: Comparison of new and re-interviewed rural sample in districts where any re-interviews took place

\begin{tabular}{lcc}
\hline & $\begin{array}{c}\text { New } \\
\text { Sample }\end{array}$ & $\begin{array}{c}\text { Re-interviewed } \\
\text { Sample }\end{array}$ \\
\hline Household Characteristics & & \\
\hline Social group & & 18 \\
Forward Caste Hindu & 16 & 35 \\
OBC & 38 & 26 \\
Dalit & 23 & 10 \\
Adivasi & 12 & 9 \\
Muslim & 9 & 2 \\
Christian, Sikh, Jain & 2 & \\
Place of Residence & & 0 \\
Metro & 0 & 1 \\
Other urban & 1 & 45 \\
More developed village & 50 & 54 \\
Less developed village & 49 & \\
Maximum adult education & & 29 \\
Iliterate & 30 & 10 \\
1-4 Std & 10 & 33 \\
5-9 Std & 34 & 12 \\
10-11 Std & 11 & 8 \\
12 Some college & 8 & 8 \\
College graduate & 7 & \\
Household income & & 3 \\
Negative-Rs 999 & 3 & 23 \\
1st Quintile (Rs 1,000-14,000) & 27 & 18 \\
2nd Quintile (Rs 14,001-22,950) & 24 & 12 \\
3rd Quintile (Rs 22,951-36,097) & 19 & 17 \\
4th Quintile (Rs 36,098-69,000) & 10 & \\
5th Quintile (Rs 69,001+) & 19 & \\
\hline Note: Table copied from Desai etal.(2010). Resuls in & \\
\hline
\end{tabular}

Note: Table copied from Desai et.al.(2010). Results in terms of the total sample 
Table 2: Proportions estimations

\begin{tabular}{llcccc}
\hline & & Proportion & Robust Std. Err. & [95\% Conf. & Interval] \\
\hline poor1994 & 0 & 0,63 & 0,011 & 0,61 & 0,65 \\
& 1 & 0,37 & 0,011 & 0,35 & 0,39 \\
poor2005 & 0 & 0,59 & 0,010 & 0,57 & 0,61 \\
& 1 & 0,41 & 0,010 & 0,39 & 0,43 \\
\hline
\end{tabular}

Note: Std. Err.adjusted for 788 clusters. IHDS design weights are used to get population estimates. 
Table 3:Poverty Flows

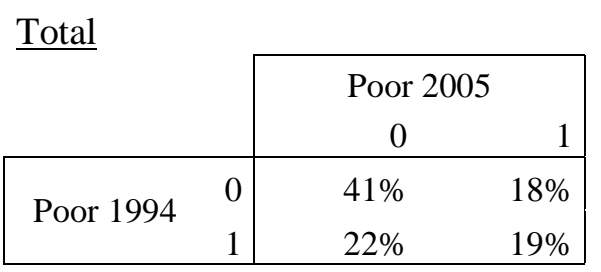

Obs. in mill.

Flows by Caste

\begin{tabular}{|c|c|c|c|c|c|c|c|c|c|c|c|c|c|}
\hline & & \multicolumn{2}{|c|}{ High Caste } & \multicolumn{2}{|c|}{ OBC } & \multicolumn{2}{|c|}{ Dalit } & \multicolumn{2}{|c|}{ Adivasi } & \multicolumn{2}{|c|}{ Muslim } & \multicolumn{2}{|c|}{ Minorities } \\
\hline & & \multicolumn{12}{|c|}{ Poor 2005} \\
\hline & & 0 & 1 & 0 & 1 & 0 & 1 & 0 & 1 & 0 & 1 & 0 & 1 \\
\hline \multirow{2}{*}{ Poor 1994} & 0 & $56 \%$ & $14 \%$ & $44 \%$ & $17 \%$ & $32 \%$ & $22 \%$ & $32 \%$ & $20 \%$ & $32 \%$ & $19 \%$ & $63 \%$ & $20 \%$ \\
\hline & 1 & $19 \%$ & $10 \%$ & $24 \%$ & $15 \%$ & $22 \%$ & $25 \%$ & $22 \%$ & $25 \%$ & $25 \%$ & $24 \%$ & $14 \%$ & $4 \%$ \\
\hline Obs. in mill. & & \multicolumn{2}{|c|}{12,70} & \multicolumn{2}{|c|}{24,4} & \multicolumn{2}{|c|}{18,6} & \multicolumn{2}{|c|}{6,8} & \multicolumn{2}{|c|}{6,3} & \multicolumn{2}{|c|}{1,2} \\
\hline
\end{tabular}

Flows by Region

\begin{tabular}{|c|c|c|c|c|c|c|c|c|c|c|c|c|c|}
\hline & \multicolumn{2}{|c|}{ Northern } & \multicolumn{2}{|c|}{ Upper Central } & \multicolumn{2}{|c|}{ Lower Central } & \multicolumn{2}{|c|}{ Western } & \multicolumn{2}{|c|}{ Eastern } & \multicolumn{2}{|c|}{ Southern } \\
\hline & & \multicolumn{12}{|c|}{ Poor 2005} \\
\hline & & 0 & 1 & 0 & 1 & 0 & 1 & 0 & 1 & 0 & 1 & 0 & 1 \\
\hline \multirow{2}{*}{ Poor 1994} & 0 & $56 \%$ & $19 \%$ & $32 \%$ & $21 \%$ & $36 \%$ & $18 \%$ & $46 \%$ & $14 \%$ & $33 \%$ & $24 \%$ & $55 \%$ & $15 \%$ \\
\hline & 1 & $13 \%$ & $12 \%$ & $26 \%$ & $21 \%$ & $24 \%$ & $22 \%$ & $23 \%$ & $16 \%$ & $18 \%$ & $25 \%$ & $19 \%$ & $11 \%$ \\
\hline Obs. in mill. & & \multicolumn{2}{|c|}{4,5} & \multicolumn{2}{|c|}{16,1} & \multicolumn{2}{|c|}{16,0} & \multicolumn{2}{|c|}{11,8} & \multicolumn{2}{|c|}{8,7} & \multicolumn{2}{|c|}{12,9} \\
\hline
\end{tabular}

Note: Flows are calculated as shares of the total samples of each group (Obs.in mill). Design weights are used to get population estimates. 
Table 4: Convergence Results

\begin{tabular}{|c|c|c|}
\hline & $\begin{array}{l}\text { Income growth } \\
\qquad g_{y}\end{array}$ & $\begin{array}{l}\text { Consumption growth } \\
\qquad g_{c}\end{array}$ \\
\hline$y_{0}$ & $\begin{array}{c}-0.076^{* * *} \\
{[0.002]}\end{array}$ & \\
\hline$c_{0}$ & & $\begin{array}{c}-0.079 * * * \\
{[0.002]}\end{array}$ \\
\hline (omitted: edu_illitarate) & & \\
\hline edu_primary & $\begin{array}{c}0.005 * * \\
{[0.002]}\end{array}$ & $\begin{array}{c}0.004 * * * \\
{[0.001]}\end{array}$ \\
\hline edu_middle & $\begin{array}{c}0.014 * * * \\
{[0.003]}\end{array}$ & $\begin{array}{c}0.009 * * * \\
{[0.002]}\end{array}$ \\
\hline edu_secondary & $\begin{array}{c}0.034^{* * *} \\
{[0.006]}\end{array}$ & $\begin{array}{c}0.020^{* * *} \\
{[0.003]}\end{array}$ \\
\hline (omitted: share_mid) & -0.011 & 0.007 \\
\hline & {$[0.009]$} & {$[0.008]$} \\
\hline share_children & $\begin{array}{l}-0,005 \\
{[0.005]}\end{array}$ & $\begin{array}{l}-0,001 \\
{[0.003]}\end{array}$ \\
\hline (omitted: caste_high) & & \\
\hline caste_OBC & $\begin{array}{c}-0.011 * * * \\
{[0.003]}\end{array}$ & $\begin{array}{c}-0.005 * * * \\
{[0.002]}\end{array}$ \\
\hline caste_SC & $\begin{array}{c}-0.019 * * * \\
{[0.003]}\end{array}$ & $\begin{array}{c}-0.013 * * * \\
{[0.002]}\end{array}$ \\
\hline caste_ST & $\begin{array}{c}-0.017 * * * \\
{[0.005]}\end{array}$ & $\begin{array}{c}-0.016^{* * * *} \\
{[0.002]}\end{array}$ \\
\hline muslim & $\begin{array}{c}-0.020 * * * \\
{[0.005]}\end{array}$ & $\begin{array}{c}-0.008 * * * \\
{[0.003]}\end{array}$ \\
\hline others & $\begin{array}{c}-0,006 \\
{[0.006]}\end{array}$ & $\begin{array}{c}0,001 \\
{[0.003]}\end{array}$ \\
\hline $\begin{array}{l}\text { (omitted: male) } \\
\text { Female }\end{array}$ & 0,005 & $0.005 * *$ \\
\hline & {$[0.004]$} & {$[0.003]$} \\
\hline age_mid & $\begin{array}{c}-0.013 * * * \\
{[0.002]}\end{array}$ & $\begin{array}{c}-0.004 * * * \\
{[0.001]}\end{array}$ \\
\hline age_old & $\begin{array}{c}0,002 \\
{[0.003]}\end{array}$ & $\begin{array}{c}0 \\
{[0.002]}\end{array}$ \\
\hline (omitted: ocu_agri) & & \\
\hline ocu_proff & $\begin{array}{c}0.009 * * * \\
{[0.002]}\end{array}$ & $\begin{array}{c}0 \\
{[0.001]}\end{array}$ \\
\hline ocu_own & $\begin{array}{c}0.012^{* * * *} \\
{[0.003]}\end{array}$ & $\begin{array}{c}0,001 \\
{[0.002]}\end{array}$ \\
\hline ocu_none & $\begin{array}{l}0.007^{*} \\
{[0.004]}\end{array}$ & $\begin{array}{l}-0,001 \\
{[0.002]}\end{array}$ \\
\hline exp_edu & $\begin{array}{c}0.060 * * * \\
{[0.016]}\end{array}$ & $\begin{array}{c}0,008 \\
{[0.007]}\end{array}$ \\
\hline assets & $\begin{array}{c}0.002^{* * *} \\
{[0.000]}\end{array}$ & $\begin{array}{c}0.001^{* * *} \\
{[0.000]}\end{array}$ \\
\hline split & $\begin{array}{l}-0.004^{*} \\
{[0.002]}\end{array}$ & $\begin{array}{c}0,001 \\
{[0.001]}\end{array}$ \\
\hline Constant & $\begin{array}{c}0.689 * * * \\
{[0.015]}\end{array}$ & $\begin{array}{c}0.669 * * * \\
{[0.015]}\end{array}$ \\
\hline $\begin{array}{l}\text { Observations } \\
\text { R-squared }\end{array}$ & $\begin{array}{l}12352 \\
0,456\end{array}$ & $\begin{array}{l}12327 \\
0,438\end{array}$ \\
\hline
\end{tabular}

Note: Standard errors allow for intra-village correlation. Coefficients for states are ommitted. ${ }^{* * *}$ : statistically significant at $1 \%$; **: statistically significant at $5 \%$; *:statistically significant at $10 \%$; ++: statistically significant at $15 \%$; +: statistically significant at $20 \%$. 


\begin{tabular}{|c|c|c|c|}
\hline & $\begin{array}{c}\text { Income } \\
y_{t}\end{array}$ & $\begin{array}{c}\text { Income } \\
\text { with instrument } \\
y_{t} \\
\end{array}$ & $\begin{array}{c}\text { Income growth } \\
\text { with instrument } \\
g_{y} \\
\end{array}$ \\
\hline$y_{0}$ & $\begin{array}{c}0.161^{* * *} \\
{[0.017]}\end{array}$ & $\begin{array}{c}0.241^{* * *} \\
{[0.055]}\end{array}$ & $\begin{array}{c}-0.069 * * * \\
{[0.055]}\end{array}$ \\
\hline \multicolumn{4}{|l|}{$\begin{array}{l}c_{0} \\
\text { (omitted: edu_illitarate) }\end{array}$} \\
\hline edu_primary & $\begin{array}{l}0.050 * * \\
{[0.025]}\end{array}$ & $\begin{array}{l}0.044 * \\
{[0.026]}\end{array}$ & $\begin{array}{l}0.004 * \\
{[0.002]}\end{array}$ \\
\hline edu_middle & $\begin{array}{c}0.156^{* * * *} \\
{[0.035]}\end{array}$ & $\begin{array}{c}0.135 * * * \\
{[0.037]}\end{array}$ & $\begin{array}{c}0.012^{* * * *} \\
{[0.003]}\end{array}$ \\
\hline edu_secondary & $\begin{array}{c}0.379 * * * \\
{[0.069]}\end{array}$ & $\begin{array}{c}0.332 * * * \\
{[0.072]}\end{array}$ & $\begin{array}{c}0.030^{* * *} \\
{[0.007]}\end{array}$ \\
\hline (omitted: share_mid) & & & \\
\hline share_old & $\begin{array}{l}-0,122 \\
{[0.096]}\end{array}$ & $\begin{array}{c}-0.125+ \\
{[0.093]}\end{array}$ & $\begin{array}{c}-0.011+ \\
{[0.008]}\end{array}$ \\
\hline share_children & $\begin{array}{l}-0,057 \\
{[0.057]}\end{array}$ & $\begin{array}{c}0,023 \\
{[0.082]}\end{array}$ & $\begin{array}{c}0,002 \\
{[0.007]}\end{array}$ \\
\hline $\begin{array}{l}\text { (omitted: caste_high) } \\
\text { caste OBC }\end{array}$ & $-0117 * * *$ & & \\
\hline caste_OBC & $\begin{array}{c}-0.11 / 37 * \\
{[0.037]}\end{array}$ & $\begin{array}{c}-0.108^{* * *} \\
{[0.037]}\end{array}$ & $\begin{array}{c}-0.010^{* * * 3} \\
{[0.003]}\end{array}$ \\
\hline caste_SC & $\begin{array}{c}-0.214 * * * \\
{[0.063]}\end{array}$ & $\begin{array}{c}-0.176^{* * *} \\
{[0.065]}\end{array}$ & $\begin{array}{l}-0.018^{* * * *} \\
{[0.003]}\end{array}$ \\
\hline caste_ST & $\begin{array}{c}-0.190^{* *} \\
{[0.052]}\end{array}$ & $\begin{array}{c}-0.149 * * \\
{[0.072]}\end{array}$ & $\begin{array}{c}-0.015^{* *} \\
{[0.005]}\end{array}$ \\
\hline muslim & $\begin{array}{c}-0.218 * * * \\
{[0.051]}\end{array}$ & $\begin{array}{c}-0.213 * * * \\
{[0.051]}\end{array}$ & $\begin{array}{c}-0.015 * * * \\
{[0.005]}\end{array}$ \\
\hline others & $\begin{array}{c}-0,064 \\
{[0.062]}\end{array}$ & $\begin{array}{l}-0,056 \\
{[0.064]}\end{array}$ & $\begin{array}{l}-0.005 \\
{[0.006]}\end{array}$ \\
\hline $\begin{array}{l}\text { Female } \\
\text { Femited: male) }\end{array}$ & $\begin{array}{c}0,057 \\
{[0.048]}\end{array}$ & $\begin{array}{c}0,045 \\
{[0.049]}\end{array}$ & $\begin{array}{c}0,004 \\
{[0.004]}\end{array}$ \\
\hline (omitted: age_young) & & & \\
\hline age_mid & $\begin{array}{c}-0.144 * * * \\
{[0.024]}\end{array}$ & $\begin{array}{c}-0.137 * * * \\
{[0.024]}\end{array}$ & $\begin{array}{c}-0.012 * * * \\
{[0.002]}\end{array}$ \\
\hline age_old & $\begin{array}{c}0,019 \\
{[0.031]}\end{array}$ & $\begin{array}{c}0,024 \\
{[0.031]}\end{array}$ & $\begin{array}{c}0,002 \\
{[0.003]}\end{array}$ \\
\hline (omitted: ocu_agri) & & $0115 * * *$ & \\
\hline ocu_proft & $\begin{array}{c}0.099^{* * *} \\
{[0.026]}\end{array}$ & $\begin{array}{c}0.115^{* * *} \\
{[0.027]}\end{array}$ & $\begin{array}{c}0.010^{* * *} \\
{[0.002]}\end{array}$ \\
\hline ocu_own & $\begin{array}{c}0.132 * * * \\
{[0.033]}\end{array}$ & $\begin{array}{c}0.138 * * * \\
{[0.033]}\end{array}$ & $\begin{array}{c}0.013^{* * *} \\
{[0.003]}\end{array}$ \\
\hline ocu_none & $\begin{array}{l}0.074^{*} \\
{[0.041]}\end{array}$ & $\begin{array}{l}0.097 * * \\
{[0.044]}\end{array}$ & $\begin{array}{l}0.009 * \\
{[0.004]}\end{array}$ \\
\hline exp_edu & $\begin{array}{c}0.656^{* * * *} \\
{[0.179]}\end{array}$ & $\begin{array}{c}0.878 * * * \\
{[0.231]}\end{array}$ & $\begin{array}{c}0.080 * * * \\
{[0.021]}\end{array}$ \\
\hline assets & $\begin{array}{c}0.018^{* * * *} \\
{[0.002]}\end{array}$ & $\begin{array}{c}0.016 * * * \\
{[0.003]}\end{array}$ & $\begin{array}{c}0.0014 * * * \\
{[0.000]}\end{array}$ \\
\hline split & $\begin{array}{l}-0.043^{*} \\
{[0.024]}\end{array}$ & $\begin{array}{l}-0,028 \\
{[0.027]}\end{array}$ & $\begin{array}{l}-0,003 \\
{[0.002]}\end{array}$ \\
\hline Constant & $\begin{array}{c}7.578 * * * \\
{[0.165]}\end{array}$ & $\begin{array}{c}6.827 * * * \\
{[0.516]}\end{array}$ & $\begin{array}{c}0.621^{* * * *} \\
{[0.047]}\end{array}$ \\
\hline Observations & 12352 & 12352 & 12352 \\
\hline R-squared & 0,19 & 0,186 & \\
\hline
\end{tabular}

Note: Standard errors allow for intra-village correlation. Coefficients for states are ommitted. ***: statistically significant at $1 \%$; **: statistically significant at $5 \%$; *:statistically significant at $10 \%$; ++: statistically significant at $15 \%$; +: statistically significant at $20 \%$. 
Table 6: Marginal average effects of the biprobit model

\begin{tabular}{|c|c|c|}
\hline & $\operatorname{Pr}($ poor05=1) & $\operatorname{Pr}($ poor $05=1 \mathrm{l}$ poor94=1) \\
\hline \multicolumn{3}{|l|}{ (omitted: edu_illitarate) } \\
\hline edu_primary & $-0.027 *$ & $-0.027 *$ \\
\hline edu middle & $-0.065 * * *$ & $-0.065 * * *$ \\
\hline & {$[0.022]$} & {$[0.023]$} \\
\hline edu_secondary & $-0.112 * * *$ & -0.114 \\
\hline \multicolumn{2}{|l|}{ (omitted: ocu_agri) } & [13.73] \\
\hline ocu_proff & $\begin{array}{l}-0.053 * * * \\
{[0.016]}\end{array}$ & $\begin{array}{l}-0.053 * * * \\
{[0.016]}\end{array}$ \\
\hline ocu_own & $\begin{array}{l}-0.067 * * * \\
{[0.023]}\end{array}$ & $\begin{array}{l}-0.068 * * \\
{[0.030]}\end{array}$ \\
\hline ocu_none & $\begin{array}{l}-0,037 \\
{[0.028]}\end{array}$ & $\begin{array}{l}-0.036 \\
{[0.027]}\end{array}$ \\
\hline \multicolumn{3}{|l|}{ (omitted: caste_high) } \\
\hline caste_OBC & $\begin{array}{l}0.038 * \\
{[0.022]}\end{array}$ & $\begin{array}{l}0.037 * \\
{[0.022]}\end{array}$ \\
\hline caste_SC & $\begin{array}{l}0.096 * * * \\
{[0.023]}\end{array}$ & $\begin{array}{l}0.095 * * * \\
{[0.024]}\end{array}$ \\
\hline caste_ST & $\begin{array}{l}0.099 * * * \\
{[0.029]}\end{array}$ & $\begin{array}{l}0.098 * * \\
{[0.029]}\end{array}$ \\
\hline muslim & $\begin{array}{l}0.126 * * * \\
{[0.031]}\end{array}$ & $\begin{array}{l}0.123 * * * \\
{[0.032]}\end{array}$ \\
\hline others & $\begin{array}{l}-0,029 \\
{[0.039]}\end{array}$ & $\begin{array}{l}-0.028 \\
{[0.038]}\end{array}$ \\
\hline (omitted: male) & & \\
\hline female & $\begin{array}{l}-0.076 * * * \\
{[0.029]}\end{array}$ & $\begin{array}{l}-0.074 * * * \\
{[0.025]}\end{array}$ \\
\hline (omitted: age_young) & & \\
\hline age_mid & $\begin{array}{l}0.090^{* * *} \\
{[0.020]}\end{array}$ & $\begin{array}{l}0.088 * * * \\
{[0.019]}\end{array}$ \\
\hline age_old & $\begin{array}{l}0,007 \\
{[0.019]}\end{array}$ & $\begin{array}{l}0.006 \\
{[0.018]}\end{array}$ \\
\hline (omitted: share_mid) & & \\
\hline share_old & $\begin{array}{l}0,066 \\
{[0.049]}\end{array}$ & $\begin{array}{l}0.065 \\
{[0.048]}\end{array}$ \\
\hline share_children & $\begin{array}{l}0.085^{* * * *} \\
{[0.032]}\end{array}$ & $\begin{array}{l}0.090 * * \\
{[0.034]}\end{array}$ \\
\hline assets & $\begin{array}{l}-0.009 * * * \\
{[0.001]}\end{array}$ & $\begin{array}{l}-0.009 * * * \\
{[0.001]}\end{array}$ \\
\hline Split & $\begin{array}{l}0.023+ \\
{[0.014]}\end{array}$ & $\begin{array}{l}0.024 \\
{[0.014]}\end{array}$ \\
\hline poor1994 & $\begin{array}{l}0.081^{* * *} \\
{[0.018]}\end{array}$ & $\begin{array}{l}0.104 * * \\
{[0.052]}\end{array}$ \\
\hline Land & & $\begin{array}{l}0,00 \\
{[0.000]}\end{array}$ \\
\hline exp_edu & $\begin{array}{l}-0.207 * \\
{[0.115]}\end{array}$ & $\begin{array}{l}-0.167 \\
{[0.124]}\end{array}$ \\
\hline Observations & 12.352 & 12352 \\
\hline
\end{tabular}

Note: Standard errors allow for intra-village correlation. Reference groups are 1. eduh (illiterate), 1.sexh(male), 1.ageh(<30 years), sna (share of people 15-50 yrs old), 2.state(Himachal Pradesh). Coefficients for states are ommitted. ***: statistically significant at $1 \%$; **: statistically significant at $5 \%$; *statistically significant at $10 \%$; ++: statistically significant at $15 \%$; +: statistically significant at $20 \%$. 
Table 7: Joint and conditional predicted probabilities

\begin{tabular}{|c|c|c|c|c|c|c|c|c|c|c|c|c|c|}
\hline & \multicolumn{7}{|c|}{ Caste } & \multicolumn{6}{|c|}{ Region } \\
\hline & Total & High Cast & OBC & Dalit & Adivasi & Muslim & Minorities & Northern & $\begin{array}{l}\text { Upper } \\
\text { Central }\end{array}$ & $\begin{array}{l}\text { Lower } \\
\text { Central }\end{array}$ & Western & Eastern & Southern \\
\hline \multicolumn{14}{|l|}{ Joint probabilities } \\
\hline $\mathrm{P}($ poor05=1, poor94=1) & $16 \%$ & $7 \%$ & $14 \%$ & $21 \%$ & $24 \%$ & $22 \%$ & $4 \%$ & $8 \%$ & $21 \%$ & $21 \%$ & $12 \%$ & $24 \%$ & $9 \%$ \\
\hline $\mathrm{P}($ poor05=0, poor94=1) & $20 \%$ & $17 \%$ & $19 \%$ & $24 \%$ & $22 \%$ & $22 \%$ & $17 \%$ & $23 \%$ & $21 \%$ & $20 \%$ & $17 \%$ & $27 \%$ & $18 \%$ \\
\hline $\mathrm{P}($ poor05=1, poor94=0) & $23 \%$ & $20 \%$ & $25 \%$ & $23 \%$ & $26 \%$ & $26 \%$ & $12 \%$ & $15 \%$ & $27 \%$ & $27 \%$ & $26 \%$ & $21 \%$ & $20 \%$ \\
\hline $\mathrm{P}($ poor05=0, poor94=0) & $41 \%$ & $55 \%$ & $42 \%$ & $31 \%$ & $28 \%$ & $29 \%$ & $67 \%$ & $53 \%$ & $31 \%$ & $33 \%$ & $44 \%$ & $28 \%$ & $53 \%$ \\
\hline \multicolumn{14}{|l|}{ Conditional probabilities } \\
\hline $\mathrm{P}($ poor05=1 | poor94=1) & $37 \%$ & $25 \%$ & $37 \%$ & $43 \%$ & $48 \%$ & $47 \%$ & $14 \%$ & $22 \%$ & $46 \%$ & $45 \%$ & $36 \%$ & $44 \%$ & $27 \%$ \\
\hline $\mathrm{P}($ poor05=0 $\mid$ poor94=1) & $63 \%$ & $75 \%$ & $63 \%$ & $57 \%$ & $52 \%$ & $53 \%$ & $86 \%$ & $78 \%$ & $54 \%$ & $55 \%$ & $64 \%$ & $56 \%$ & $73 \%$ \\
\hline $\mathrm{P}($ poor05=1 | poor94=0) & $40 \%$ & $28 \%$ & $40 \%$ & $46 \%$ & $51 \%$ & $50 \%$ & $16 \%$ & $25 \%$ & $49 \%$ & $49 \%$ & $39 \%$ & $47 \%$ & $30 \%$ \\
\hline $\mathrm{P}($ poor05=0 $\mid$ poor94=0) & $60 \%$ & $72 \%$ & $60 \%$ & $54 \%$ & $49 \%$ & $50 \%$ & $84 \%$ & $75 \%$ & $51 \%$ & $51 \%$ & $61 \%$ & $53 \%$ & $70 \%$ \\
\hline
\end{tabular}


Table A.1: Description and statistics of data set

\begin{tabular}{|c|c|c|c|c|c|c|c|}
\hline Abbreviation in tables & Used Name & Description & Obs & Mean & Std. Dev. & Min & Max \\
\hline$y_{0}$ & lyo94_05pc & $\begin{array}{l}1994 \text { annual household income per capita in } 2005 \text { prices (based on rural } \\
\text { deflators by State). In logarithms. }\end{array}$ & 12352 & 8,66412 & 0,80649 & 5,19281 & 12,6018 \\
\hline \multirow[t]{4}{*}{$y_{\tau}$} & lyo05pc & 2005 annual household income per capita in constant prices. In logarithms & 12352 & 8,64649 & 0,82043 & 6,90776 & 13,1103 \\
\hline & yo05pc & 2005 annual household income per capita in constant prices & 12352 & 8433,08 & 12641,5 & 1000 & 494000 \\
\hline & y94_m0 & Demeaned income based on lyo94_05pc & & & & & \\
\hline & y05_m0 & Demeaned income based on lyo05pc & & & & & \\
\hline \multirow[t]{2}{*}{$g_{y}$} & g1p & Annual growth rate of income per capita in prices of 2005. & 12352 & $-0,0016$ & 0,08772 & $-0,4502$ & 0,48966 \\
\hline & def05 & State-level rural deflators for 1993/1994 year. Base year: 2004/2005 & 12352 & 0,57193 & 0,01875 & 0,5381 & 0,5987 \\
\hline$c_{0}$ & lc94_05p & $\begin{array}{l}1994 \text { annual household food consumption per capita in } 2005 \text { prices(based } \\
\text { on rural deflators by State) . In logarithms. The products are: cereals and } \\
\text { pulses, sugar, milk, edible oil, meat and fish, eggs, vegetables, fruits and } \\
\text { others. }\end{array}$ & 12351 & 8,0971 & 0,46163 & 5,56847 & 10,5866 \\
\hline \multirow[t]{3}{*}{$c_{\tau}$} & lc05p & $\begin{array}{l}2005 \text { annual household food consumption per capita in constant prices. In } \\
\text { logarithms. }\end{array}$ & 12328 & 8,06496 & 0,51026 & 3,17805 & 10,9474 \\
\hline & c94_m0 & Demeaned consumption based on lc94_05p & & & & & \\
\hline & c05_m0 & Demeaned income based on lc05p & & & & & \\
\hline$g_{c}$ & gсрс & Annual growth rate of food consumption per capita in prices of 2005. & 12327 & $-0,0029$ & 0,05005 & $-0,4188$ & 0,2455 \\
\hline \multirow[t]{2}{*}{$p_{0}$} & poor94= 1 & $\begin{array}{l}\text { Poor, if current income per capita in } 1994 \text { is below the poverty line in } \\
1994 .\end{array}$ & 12352 & $36 \%$ & 0,47934 & 0 & 1 \\
\hline & poor94 $=0$ & $\begin{array}{l}\text { Non poor, if current income per capita in } 1994 \text { is above the poverty line in } \\
1994 .\end{array}$ & 12352 & $64 \%$ & 0,47934 & 0 & 1 \\
\hline \multirow[t]{2}{*}{$p_{\tau}$} & poor $05=1$ & $\begin{array}{l}\text { Poor, if current income per capita in } 2005 \text { is below the poverty line of } \\
2005 .\end{array}$ & 12352 & $39 \%$ & 0,4884 & 0 & 1 \\
\hline & poor05 $=0$ & $\begin{array}{l}\text { Non poor if current income per capita in } 2005 \text { is above the poverty line } \\
\text { of } 2005 \text {. }\end{array}$ & 12352 & $61 \%$ & 0,4884 & 0 & 1 \\
\hline exp_edu & rexe94 & Share of expenses on education of total annual household income. & 12352 & 0,03386 & 0,09078 & 0 & 4,2739 \\
\hline assets & ass94 & $\begin{array}{l}\text { Sum of weighted productive and unproductive asset index. Productive } \\
\text { assets: tractor, winnower, etc. Unproductive assets: car, bicycle, } \\
\text { television, etc. }\end{array}$ & 12352 & 4,88196 & 6,8805 & 0 & 63 \\
\hline share_ad & sna & $\begin{array}{l}\text { Share of number of adults (15-59 yrs of age) with respect to size of } \\
\text { household. }\end{array}$ & 12352 & $59 \%$ & 0,21269 & 0 & 1 \\
\hline share_old & sno & $\begin{array}{l}\text { Share of number of old people ( more than } 59 \text { yrs of age) with respect to } \\
\text { size of household. }\end{array}$ & 12352 & $7 \%$ & 0,13919 & 0 & 1 \\
\hline \multirow[t]{3}{*}{ share_child } & snch & $\begin{array}{l}\text { Share of number of children ( 6-14 yrs of age) with respect to size of } \\
\text { household. }\end{array}$ & 12352 & $34 \%$ & 0,20969 & 0 & 1 \\
\hline & split & 1 if the original household in 1994 was split in 2005 & 12352 & 0,30149 & 0,45892 & 0 & 1 \\
\hline & vill & Village & 12352 & 386,361 & 227,17 & 1 & 789 \\
\hline Abbreviation in tables & Used Name & Description & Obs & Mean & Std. Dev. & Min & Max \\
\hline
\end{tabular}




\begin{tabular}{|c|c|c|c|c|c|c|c|}
\hline edu_illi & 1.eduh & Head of household's education. Illiterate & 12352 & $51 \%$ & 0,4999 & 0 & 1 \\
\hline edu_prim & 2.eduh & Primary education & 12352 & $28 \%$ & 0,44986 & 0 & 1 \\
\hline edu_mid & 3.eduh & Middle education and Matriculation & 12352 & $17 \%$ & 0,37409 & 0 & 1 \\
\hline edu_sec & 4.eduh & Secondary education and above & 12352 & $4 \%$ & 0,19404 & 0 & 1 \\
\hline caste_up & 1.castrel05 & Head of household's caste. Brahmin+ Forward castes & 12352 & $21 \%$ & 0,40733 & 0 & 1 \\
\hline caste_OBC & 2.castrel05 & Other Backward Classes (OBC) & 12352 & $34 \%$ & 0,47274 & 0 & 1 \\
\hline caste_SC & 3.castrel05 & Dalit or Scheduled Castes (SC) & 12352 & $25 \%$ & 0,43308 & 0 & 1 \\
\hline caste_ST & 4.castrel05 & Adivasi or Scheduled Tribes (ST) & 12352 & $9 \%$ & 0,29318 & 0 & 1 \\
\hline muslim & 5.castrel05 & Muslim & 12352 & $8 \%$ & 0,26952 & 0 & 1 \\
\hline others & 6.castrel05 & Sikh, Jain and Christian & 12352 & $3 \%$ & 0,16777 & 0 & 1 \\
\hline male & 1.sexh & Head of household's gender. Male & 12352 & $95 \%$ & 0,20805 & 0 & 1 \\
\hline female & 2.sexh & Female & 12352 & $5 \%$ & 0,20805 & 0 & 1 \\
\hline young_age & 1.ageh & Head of household's age. $<30$ years & 12352 & $60 \%$ & 0,48942 & 0 & 1 \\
\hline ad_age & 2.ageh & $31-55$ years & 12352 & $15 \%$ & 0,35487 & 0 & 1 \\
\hline old_age & 3.ageh & $>55$ years & 12352 & $25 \%$ & 0,43294 & 0 & 1 \\
\hline ocu_agri & 1.ocuh & Head of household's ocupation. Cultivation+allied agriculture+cattle & 12352 & $48 \%$ & 0,49964 & 0 & 1 \\
\hline ocu_prof & 2.ocuh & Wages, salaries and professional & 12352 & $33 \%$ & 0,47159 & 0 & 1 \\
\hline ocu_own & 3.ocuh & Own business & 12352 & $11 \%$ & 0,30957 & 0 & 1 \\
\hline ocu_none & 4.ocuh & Other (no work or work at home and not specified. & 12352 & $8 \%$ & 0,26863 & 0 & 1 \\
\hline land & land94 & $\begin{array}{l}\text { Household owns land in acres. Note: Min. and Max value is in one } \\
\text { decimal points e.g. Max. value is } 3600 \text { means } 360 \text { acres of land. }\end{array}$ & 12352 & 37,3718 & 98,0158 & 0 & 3600 \\
\hline 2.state & 2.state & Sate. Himachal Pradesh & 12352 & $6 \%$ & 0,23384 & 0 & 1 \\
\hline 3.state & 3.state & Punjab & 12352 & $6 \%$ & 0,23215 & 0 & 1 \\
\hline 5.state & 5.state & Uttaranchal & 12352 & $1 \%$ & 0,11617 & 0 & 1 \\
\hline 6.state & 6.state & Haryana & 12352 & $7 \%$ & 0,25507 & 0 & 1 \\
\hline 8.state & 8.state & Rajasthan & 12352 & $9 \%$ & 0,28201 & 0 & 1 \\
\hline 9.state & 9.state & Uttar Pradesh & 12352 & $4 \%$ & 0,20538 & 0 & 1 \\
\hline 10.state & 10.state & Bihar & 12352 & $5 \%$ & 0,21345 & 0 & 1 \\
\hline 18.state & 18.state & Assam & 12352 & $0 \%$ & 0,02698 & 0 & 1 \\
\hline 19.state & 19.state & West Bengal & 12352 & $7 \%$ & 0,26204 & 0 & 1 \\
\hline 20.state & 20.state & Jharkhand & 12352 & $2 \%$ & 0,14027 & 0 & 1 \\
\hline 21.state & 21.state & Orissa & 12352 & $7 \%$ & 0,25966 & 0 & 1 \\
\hline 22.state & 22.state & Chhatishgarh & 12352 & $5 \%$ & 0,21835 & 0 & 1 \\
\hline Abbreviation in tables & Used Name & Description & Obs & Mean & Std. Dev. & Min & Max \\
\hline
\end{tabular}




\begin{tabular}{|c|c|c|c|c|c|c|c|}
\hline 23.state & 23.state & Madhya Pradesh & 12352 & $11 \%$ & 0,30761 & 0 & 1 \\
\hline 24.state & 24.state & Gujarat & 12352 & $6 \%$ & 0,22888 & 0 & 1 \\
\hline 27.state & 27.state & Maharashtra & 12352 & $11 \%$ & 0,31474 & 0 & 1 \\
\hline 28.state & 28.state & Andhra Pradesh & 12352 & $6 \%$ & 0,24149 & 0 & 1 \\
\hline 32.state & 32.state & Kerala & 12352 & $2 \%$ & 0,15117 & 0 & 1 \\
\hline 33.state & 33.state & Tamil Nadu & 12352 & $5 \%$ & 0,20928 & 0 & 1 \\
\hline 1.region & 1.region & Region. Northern & 12352 & $19 \%$ & 0,38844 & 0 & 1 \\
\hline 2.region & 2.region & Upper Central & 12352 & $13 \%$ & 0,33156 & 0 & 1 \\
\hline 3.region & 3.region & Lower Central & 12352 & $32 \%$ & 0,46486 & 0 & 1 \\
\hline 4.region & 4.region & Western & 12352 & $17 \%$ & 0,37293 & 0 & 1 \\
\hline 5.region & 5.region & Eastern & 12352 & $7 \%$ & 0,26322 & 0 & 1 \\
\hline 6.region & 6.region & Southern & 12352 & $13 \%$ & 0,33793 & 0 & 1 \\
\hline \multirow[t]{2}{*}{ weight } & swe05 & weight from 2005 & 12352 & 5664 & 7292 & 543 & 308216 \\
\hline & & sum of weights=sum of population estimates in millons of persons & 70 & & & & \\
\hline
\end{tabular}

Note: Sample restricted to yo05pc $>=1000$. Most of variables are from 1994 survey, unless otherwise stated. 
Table A.2: Sensitivity analysis for consumption

\begin{tabular}{|c|c|c|c|}
\hline & $\begin{array}{l}\text { Consumption } \\
\qquad c_{\tau}\end{array}$ & $\begin{array}{l}\text { Consumption with } \\
\text { instrument } \\
c_{\tau} \\
\end{array}$ & $\begin{array}{l}\text { Consumption growth } \\
\text { with instrument } \\
g_{c}\end{array}$ \\
\hline \multicolumn{4}{|l|}{$y_{0}$} \\
\hline$c_{0}$ & $\begin{array}{c}0.133^{* * *} \\
{[0.018]}\end{array}$ & $\begin{array}{c}0.353++ \\
{[0.242]}\end{array}$ & $\begin{array}{c}-0.059 * * * \\
{[0.022]}\end{array}$ \\
\hline \multicolumn{4}{|l|}{ (omitted: edu_illitarate) } \\
\hline edu_primary & $\begin{array}{c}0.047 * * * \\
{[0.014]}\end{array}$ & $\begin{array}{c}0.039 * * \\
{[0.017]}\end{array}$ & $\begin{array}{c}0.004^{* *} \\
{[0.002]}\end{array}$ \\
\hline edu_middle & $\begin{array}{c}0.102 * * * \\
{[0.018]}\end{array}$ & $\begin{array}{c}0.081 * * * \\
{[0.031]}\end{array}$ & $\begin{array}{c}0.007 * * * \\
{[0.003]}\end{array}$ \\
\hline edu_secondary & $\begin{array}{c}0.216^{* * *} \\
{[0.036]}\end{array}$ & $\begin{array}{c}0.172 * * * \\
{[0.057]}\end{array}$ & $\begin{array}{c}0.015^{* * *} \\
{[0.005]}\end{array}$ \\
\hline \\
\hline share_old & $\begin{array}{c}0,08 \\
{[0.086]}\end{array}$ & $\begin{array}{c}0,069 \\
{[0.079]}\end{array}$ & $\begin{array}{c}0.006 \\
{[0.007]}\end{array}$ \\
\hline share_children & $\begin{array}{l}-0,006 \\
{[0.031]}\end{array}$ & $\begin{array}{c}0,123 \\
{[0.150]}\end{array}$ & $\begin{array}{c}0.011 \\
{[0.014]}\end{array}$ \\
\hline \multicolumn{4}{|l|}{ (omitted: caste_high) } \\
\hline caste_OBC & $\begin{array}{c}-0.056^{* * *} \\
{[0.020]}\end{array}$ & $\begin{array}{c}-0.049 * * \\
{[0.023]}\end{array}$ & $\begin{array}{c}-0.004 * * \\
{[0.002]}\end{array}$ \\
\hline caste_SC & $\begin{array}{c}-0.144 * * * \\
{[0.020]}\end{array}$ & $\begin{array}{c}-0.123^{* * *} \\
{[0.032]}\end{array}$ & $\begin{array}{l}-0.011^{*} \\
{[0.003]}\end{array}$ \\
\hline caste_ST & $\begin{array}{c}-0.180 * * * \\
{[0.028]}\end{array}$ & $\begin{array}{c}-0.147 * * * \\
{[0.047]}\end{array}$ & $\begin{array}{c}-0.013^{* * *} \\
{[0.004]}\end{array}$ \\
\hline muslim & $\begin{array}{c}-0.091 * * * \\
{[0.030]}\end{array}$ & $\begin{array}{c}-0.081 * * \\
{[0.033]}\end{array}$ & $\begin{array}{c}-0.007 * * \\
{[0.002]}\end{array}$ \\
\hline others & $\begin{array}{c}0,015 \\
{[0.037]}\end{array}$ & $\begin{array}{c}0,018 \\
{[0.039]}\end{array}$ & $\begin{array}{c}0.001 \\
{[0.004]}\end{array}$ \\
\hline \multicolumn{4}{|l|}{ (omitted: male) } \\
\hline female & $\begin{array}{l}0.058 * * \\
{[0.029]}\end{array}$ & $\begin{array}{c}0.050++ \\
{[0.031]}\end{array}$ & $\begin{array}{c}0.005++ \\
{[0.003]}\end{array}$ \\
\hline \multirow[t]{2}{*}{ age_mid } & $-0.042 * * *$ & $-0.041^{* *}$ & $-0.004 * *$ \\
\hline & [0.016] & [0.017] & [0.002] \\
\hline \multirow[t]{2}{*}{ age_old } & 0,003 & 0,01 & 0.001 \\
\hline & \multicolumn{3}{|c|}{ (omitted: ocu_agri) } \\
\hline \multirow[t]{2}{*}{ ocu_proff } & 0,004 & 0,018 & 0.002 \\
\hline & {$[0.014]$} & {$[0.021]$} & {$[0.002]$} \\
\hline \multirow[t]{2}{*}{ ocu_own } & 0,017 & 0,02 & 0,002 \\
\hline & {$[0.018]$} & {$[0.019]$} & {$[0.002]$} \\
\hline \multirow[t]{2}{*}{ ocu_none } & $-0,009$ & 0,009 & 0,001 \\
\hline & [0.024] & [0.032] & [0.003] \\
\hline \multirow[t]{2}{*}{ exp_edu } & 0,085 & 0,095 & $0.009 * * *$ \\
\hline & [0.079] & {$[0.078]$} & {$[0.007]$} \\
\hline \multirow[t]{2}{*}{ assets } & $0.008 * * *$ & $0.005 *$ & $0.000 *$ \\
\hline & {$[0.001]$} & {$[0.003]$} & {$[0.000]$} \\
\hline \multirow[t]{2}{*}{ split } & 0,006 & 0,028 & 0.003 \\
\hline & [0.014] & [0.030] & [0.003] \\
\hline \multirow[t]{2}{*}{ Constant } & $7.361 * * *$ & $5.423 * *$ & $0.45^{* *}$ \\
\hline & {$[0.161]$} & [2.118] & [0.193] \\
\hline Observations & 12327 & 12327 & 12327 \\
\hline R-squared & 0,26 & 0,231 & \\
\hline
\end{tabular}

Note: Standard errors allow for intra-village correlation. Coefficients for states are ommitted. ***: statistically significant at $1 \%$; **: statistically significant at $5 \%$; *:statistically significant at $10 \%$; ++: statistically significant at $15 \%$; +: statistically significant at $20 \%$. 
Table A.3: $\beta$-convergence parameters

\begin{tabular}{|c|c|c|c|c|}
\hline & \multicolumn{2}{|c|}{ Income } & \multicolumn{2}{|c|}{ Consumption } \\
\hline & & IV & & IV \\
\hline$\beta(Y)$ & $7,6 \%$ & $6,9 \%$ & & \\
\hline$\beta(C)$ & & & $7,9 \%$ & $5,9 \%$ \\
\hline Half-life & 9 & 10 & 9 & 12 \\
\hline \multicolumn{5}{|c|}{ Test of endogeneity } \\
\hline \multicolumn{5}{|c|}{ Ho: variable is exogenous } \\
\hline F-test & & 2,24 & & 1,14 \\
\hline p-value & & 0,130 & & 0,285 \\
\hline \multicolumn{5}{|c|}{ Explanation power of IV } \\
\hline $\mathrm{R} 2$ & & 0,390 & & 0,319 \\
\hline Adjusted R2 & & 0,387 & & 0,317 \\
\hline Partial R2 & & 0,044 & & 0,004 \\
\hline F-test & & 9,74 & & 7,87 \\
\hline prob $>F$ & & 0,002 & & 0,005 \\
\hline
\end{tabular}


Table A.4.: Estimated coefficients from probit and biprobit models

\begin{tabular}{|c|c|c|c|}
\hline & \multirow{2}{*}{$\begin{array}{c}\text { Probit } \\
\text { poor2005 }\end{array}$} & \multicolumn{2}{|c|}{ Biprobit } \\
\hline & & poor2005 & poor1994 \\
\hline \multicolumn{4}{|l|}{ (omitted: edu_illitarate) } \\
\hline edu_primary & $\begin{array}{c}-0.075^{*} \\
{[0.042]}\end{array}$ & $\begin{array}{c}-0.073 * \\
{[0.044]}\end{array}$ & $\begin{array}{c}-0.115^{* *} \\
{[0.050]}\end{array}$ \\
\hline edu_middle & $\begin{array}{c}-0.182 * * * \\
{[0.063]}\end{array}$ & $\begin{array}{c}-0.174 * * \\
{[0.069]}\end{array}$ & $\begin{array}{c}-0.403 * * * \\
{[0.074]}\end{array}$ \\
\hline edu_secondary & $\begin{array}{c}-0.322 * * * \\
{[0.113]}\end{array}$ & $\begin{array}{c}-0.301^{* *} \\
{[0.118]}\end{array}$ & $\begin{array}{c}-0.955^{* * *} \\
{[0.135]}\end{array}$ \\
\hline \multicolumn{4}{|l|}{ (omitted: share_mid) } \\
\hline share_old & $\begin{array}{c}0,185 \\
{[0.137]}\end{array}$ & $\begin{array}{c}0,185 \\
{[0.136]}\end{array}$ & $\begin{array}{c}0,1 \\
{[0.203]}\end{array}$ \\
\hline share_children & $\begin{array}{c}0.243 * * * \\
{[0.091]}\end{array}$ & $\begin{array}{l}0.200^{*} \\
{[0.114]}\end{array}$ & $\begin{array}{c}1.756 * * * \\
{[0.104]}\end{array}$ \\
\hline \multicolumn{4}{|l|}{ (omitted: caste_high) } \\
\hline caste_OBC & $\begin{array}{c}0.107^{*} \\
{[0.062]}\end{array}$ & $\begin{array}{c}0.105^{*} \\
{[0.063]}\end{array}$ & $\begin{array}{c}0.125^{*} \\
{[0.074]}\end{array}$ \\
\hline caste_SC & $\begin{array}{c}0.270 * * * \\
{[0.063]}\end{array}$ & $\begin{array}{c}0.239 * * \\
{[0.112]}\end{array}$ & $\begin{array}{c}0.215^{* *} \\
{[0.083]}\end{array}$ \\
\hline caste_ST & $\begin{array}{c}0.278 * * \\
{[0.081]}\end{array}$ & $\begin{array}{l}0.248 * * \\
{[0.115]}\end{array}$ & $\begin{array}{c}0.364 * * * \\
{[0.098]}\end{array}$ \\
\hline muslim & $\begin{array}{c}0.349 * * * \\
{[0.086]}\end{array}$ & $\begin{array}{c}0.346 * * * \\
{[0.087]}\end{array}$ & $\begin{array}{c}0,107 \\
{[0.103]}\end{array}$ \\
\hline others & $\begin{array}{c}-0,088 \\
{[0.118]}\end{array}$ & $\begin{array}{c}-0,084 \\
{[0.118]}\end{array}$ & $\begin{array}{c}-0,007 \\
{[0.170]}\end{array}$ \\
\hline female & $\begin{array}{c}-0.218 * * \\
{[0.086]}\end{array}$ & $\begin{array}{c}-0.214^{* *} \\
{[0.087]}\end{array}$ & $\begin{array}{c}-0.193 * * \\
{[0.093]}\end{array}$ \\
\hline \multicolumn{4}{|l|}{ (omitted: age_young) } \\
\hline age_mid & $\begin{array}{c}0.247 * * * \\
{[0.054]}\end{array}$ & $\begin{array}{c}0.246 * * * \\
{[0.054]}\end{array}$ & $\begin{array}{c}0,06 \\
{[0.057]}\end{array}$ \\
\hline age_old & $\begin{array}{c}0,017 \\
{[0.052]}\end{array}$ & $\begin{array}{c}0,016 \\
{[0.053]}\end{array}$ & $\begin{array}{c}0,091 \\
{[0.076]}\end{array}$ \\
\hline \multicolumn{4}{|l|}{ (omitted: ocu_agri) } \\
\hline ocu_proff & $\begin{array}{c}-0.148 * * * \\
{[0.045]}\end{array}$ & $\begin{array}{c}-0.157 * * * \\
{[0.047]}\end{array}$ & $\begin{array}{l}0.117^{*} \\
{[0.062]}\end{array}$ \\
\hline ocu_own & $\begin{array}{c}-0.189 * * * \\
{[0.065]}\end{array}$ & $\begin{array}{c}-0.188 * * * \\
{[0.065]}\end{array}$ & $\begin{array}{c}-0.284 * * * \\
{[0.086]}\end{array}$ \\
\hline ocu_none & $\begin{array}{c}-0,102 \\
{[0.079]}\end{array}$ & $\begin{array}{c}-0,111 \\
{[0.080]}\end{array}$ & $\begin{array}{c}0.206 * * \\
{[0.086]}\end{array}$ \\
\hline exp_edu & $\begin{array}{c}-0.562 * \\
{[0.324]}\end{array}$ & $\begin{array}{c}-0.640^{*} \\
{[0.375]}\end{array}$ & $\begin{array}{c}4.758 * * * \\
{[0.425]}\end{array}$ \\
\hline assets & $\begin{array}{c}-0.026^{* * * *} \\
{[0.004]}\end{array}$ & $\begin{array}{c}-0.025^{* * *} * \\
{[0.004]}\end{array}$ & $\begin{array}{c}-0.044^{* * *} \\
{[0.007]}\end{array}$ \\
\hline split & $\begin{array}{l}0.064+ \\
{[0.039]}\end{array}$ & $\begin{array}{c}0,057 \\
{[0.043]}\end{array}$ & $\begin{array}{c}0.378 * * * \\
{[0.057]}\end{array}$ \\
\hline land & & & $\begin{array}{c}-0.008 * * * \\
{[0.001]}\end{array}$ \\
\hline poor94 & $\begin{array}{c}0.236 * * * \\
{[0.050]}\end{array}$ & $\begin{array}{c}0.308 * \\
{[0.165]}\end{array}$ & \\
\hline Constant & $\begin{array}{c}-0.776^{* * *} \\
{[0.119]}\end{array}$ & $\begin{array}{c}-0.783^{* * *} \\
{[0.119]}\end{array}$ & $\begin{array}{c}-1.148 * * * \\
{[0.147]}\end{array}$ \\
\hline Observations & 12.352 & 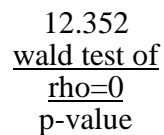 & 12.352 \\
\hline
\end{tabular}

Note: Standard errors allow for intra-village correlation. Reference groups are 1. eduh (illiterate), 1.sexh(male), 1.ageh( $<30$ years), sna (share of people 15-50 yrs old), 2.state(Himachal Pradesh). Coefficients for states are ommitted. ***: statistically significant at 1\%; **: statistically significant at $5 \%$; *:statistically significant at $10 \%$; ++: statistically significant at $15 \%$; +: statistically significant at 20 


\section{Endnotes}

${ }^{1}$ Results on poverty from different studies may differ according to the measure of poverty employed. Indeed there is an extensive debate in India about this issue, with considerable disagreement on how poverty should be measured. Deaton and Kozel (2005) argue that there is no consensus on what happened to poverty in India in the 1990s; there is good evidence both that poverty fell and that the official estimates of poverty reduction are too optimistic, particularly in rural India.

${ }^{2}$ The caste system is an ancient classification of rigid social stratification of the Indian society. Caste is endogamous, rarely changed, and implies occupational specialization.

${ }^{3}$ Affirmative action policy has been adopted in a larger scale in India than anywhere else in the world, with a nation-wide program of reservation (quotas) of new jobs, political seats and slots in higher educational institutions for the historically discriminated lowest caste groups in Indian society, the scheduled castes (SCs) and the scheduled tribes (STs). Although such quotas had existed earlier, in 1982 they were set at $15 \%$ of all public sector openings for SCs and $7.5 \%$ for STs, though varying according to fluctuations in the SC/ST population share measured during the (previous) decennial census (with administrative lags in implementation). In 1990 a further $27 \%$ of all public sector new hires were reserved for other backward castes (the OBCs).

${ }^{4}$ A seemingly natural objection here might be that we should have used adult equivalent income instead of per capita income in order to reflect the lower needs of children. To calculate the adult equivalent income variable, however, we need detailed data for all individuals in all households, and unfortunately the individual data is incomplete. Instead we use income in per capita terms since information on the total household size is available. Nevertheless, we include in the analysis information of the household composition by the three age ranges which are available in the data (share of adults, old people and children) to at least go some way toward incorporating household composition in the analysis.

${ }^{5}$ We were not able to recover expenditure on other consumption goods because of a lack of detailed information in the 1994 survey. However, our constructed variable of food consumption expenditures is still quite complete. It includes the value of purchased and home produced cereals and pulses, sugar, milk, edible oil, meat and fish, eggs, vegetables, fruits and others. We could have used consumption of cereals only but Oldiges (2012) mentions that cereal consumption seems unrelated to per capita income but that other food expenditures like fruits or meat do increase with income (normal goods), indicating that richer people do eat better.

${ }^{6}$ We are aware that the information of the head of the household may not be the only relevant information to include in the analysis. Perhaps information of the person that is most educated is also (possibly even more) relevant (Jolliffe, 2002), or that of the main earner of the household (Glewwe, 1991). Unfortunately, we could not recover individual-level data since a large share of individuals is missing. However, information on the head is complete and likely to be still quite important.

${ }^{7}$ Alternatively one could use distribution-sensitive measures of poverty ( 11 or p2). That is beyond the scope of this paper, however. 


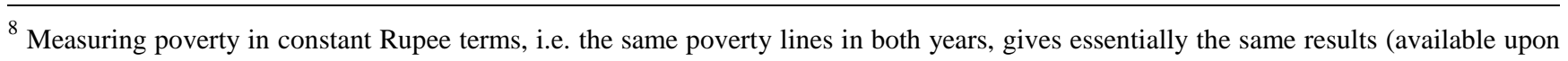
request).

${ }^{9}$ For a detailed discussion of poverty measures and poverty lines in India, see Deaton and Kozel (2005).

${ }^{10}$ Alternatively, including the variables in differences would get rid of individual unobserved effects but also time-invariant variables such as caste, which is one of the main variables we are interested in.

${ }^{11}$ For a discussion of the use of binary poverty measures versus a continuous variable, see Appleton (2001).

12 Alternatively, Ravallion (2012) analyses poverty reduction as a function of initial poverty levels.

${ }^{13}$ A detailed description of the model can be found in Greene (2008), chapter 23.

14 This concept is similar to the convergence concept, in the sense that we are interested in the situation of the initially poor and their probability of catching-up. However we do not call it poverty convergence because we are not calculating a speed of poverty reduction as in Ravallion (2012).

${ }^{15}$ We replace $\mathrm{g}_{\mathrm{yi}}=\left[\mathrm{y}_{\mathrm{ti}}-\mathrm{y}_{0 \mathrm{i}}\right] / \tau$ into Eq.(1).

${ }^{16}$ Prior research has classified historical land revenue systems as either landlord or non-landlord-based (Banerjee and Iyer, 2005). Iversen et al. (2014) show, however, that within so-called landlord systems, the zamindari system set up by the British colonial administrators in primarily Bihar and Bengal varied greatly from the malguzari system in the Central Provinces, which was closer to a village-based system.

${ }^{17}$ It is not an easy task to find other instruments. Assets, for example, are most likely endogenous: the richer the household the more assets it can buy (Glewwe, 1991).

${ }^{18}$ We estimated the same IV model for food consumption and find $\beta c=6 \%$, results in Table A.2.

${ }^{19}$ One remaining concern might be that there is reverse causality between income and assets. When we omit assets as an explanatory variable, the results remain unchanged (results available upon request).

${ }^{20}$ We are aware that this may cause problems of simultaneity.

${ }^{21}$ Results available on request. 